\title{
HIGH RATE LOW SOLIDS METHANE FERMENTATION OF SORGHUM, CORN AND CELLULOSE
}

\author{
Brian K. Richards, Robert J. Cummings and William J. Jewell \\ Department of Agricultural and Biological Engineering, Riley-Robb Hall, Cornell University, Ithaca, \\ N.Y. 14853-5701, U.S.A.
}

(Received 7 June 1991; accepted 19 December 1991)

\begin{abstract}
Sorghum, sorghum/alpha-cellulose mixture, and corn were anaerobically digested at $55^{\circ} \mathrm{C}$ at effluent solids contents of $8-12 \%$ total solids (TS), using trace nutrient supplementation. Volatile solids (VS) loading rates at much higher levels than conventional maxima were maintained without volatile fatty acid (VFA) accumulation. Semi-continuously fed digesters with organic loading rates (OLR) up to $12 \mathrm{gVS} \mathrm{kg}^{-1} \mathrm{~d}^{-1}$ produced methane at rates up to $3.3 \mathrm{~L} \mathrm{~kg}^{-1} \mathrm{~d}^{-1}$. Continuous feeding of corn at an OLR of $18 \mathrm{gVS} \mathrm{kg}^{-1} \mathrm{~d}^{-1}$ resulted in a methane production rate of $5.4 \mathrm{~L} \mathrm{~kg}^{-1} \mathrm{~d}^{-1}$. VS removal efficiencies at maximum OLRs were $60 \%$ (sorghum) and $67 \%$ (corn). At an OLR of $4 \mathrm{gVS} \mathrm{kg}^{-1} \mathrm{~d}^{-1}$, sorghum alone as a feedstock led to excess ammonia- $\mathrm{N}$ accumulation. Excess ammonia did not accumulate at sorghum loading rates of 8 and $12 \mathrm{gVS} \mathrm{kg}^{-1} \mathrm{~d}^{-1}$, nor with a sorghum/alpha-cellulose mix loaded at $8 \mathrm{gVS} \mathrm{kg}^{-1} \mathrm{~d}^{-1}$. Instantaneous gas production rates were directly related to feedstock cell soluble content, with peak instantaneous biogas production rates from corn (OLR of $8 \mathrm{gVS} \mathrm{kg}^{-1} \mathrm{~d}^{-1}$ ) approaching $25 \mathrm{~L} \mathrm{~kg}^{-1} \mathrm{~d}^{-1}$ following a three-day feeding.
\end{abstract}

Keywords-Anaerobic digestion, methane. biogas, biomass, trace nutrients, sorghum, corn, fiber analysis. $\mathrm{C}: \mathrm{N}$ ratio.

\section{INTRODUCTION}

Methane fermentation of biomass produces a clean fuel that is renewable, but economic feasibility of the process is limited by, among other factors, relatively low rates of methane production.' While extremely high conversion and production rates have been reported from $\mathrm{pH}$ controlled systems fed acetate with carefully balanced trace nutrient additions, ${ }^{2}$ methane productivitics from naturally-occurring particulate biomass are generally under $2 \mathrm{vCH}_{4} \mathrm{v}^{-1} \mathrm{~d}^{-1}$. Semi-continuously fed-and-mixed (SCFM) slurry digesters fed sorghum had maximum volumetric methane production rates of 1.5 to $1.8 \mathrm{v} \mathrm{v}^{-1} \mathrm{~d}^{-1}$ (VS loading rates of 4.8 to $\left.6 \mathrm{~g} \mathrm{~kg}^{-1} \mathrm{~d}^{-1}\right){ }^{3.4}$ Attempts to increase loading rates resulted in digester failure. A non-mixed vertical flow digester fed sorghum at a VS loading rate of $7.5 \mathrm{gVS} \mathrm{L}^{-1} \mathrm{~d}^{-1}$ produced $2.0 \mathrm{vv}^{-1} \mathrm{~d}^{-1}$ of methane.

Operation at higher digester solids contents concentrates digesting biomass and allows higher loading rates, increasing volumetric methane productivity. Rates approaching $5 \mathrm{vCH}_{4} \mathrm{v}^{-1} \mathrm{~d}^{-1}$ have been reported from digestion of the organic fraction of municipal solid waste. ${ }^{6,7}$ Digestion of a 1:1 sorghum/alphacellulose mix yielded methane productivities of up to $7.5 \mathrm{~L} \mathrm{~kg}^{-1} \mathrm{~d}^{-1}$ at $28-29 \%$ effluent total solids. ${ }^{8}$ Trace nutrient supplementation was required for stable operation.

The experiments described here were run to determine the potential for high rate operation of low solids ( $8-12 \%$ effluent TS) systems at methane productivities higher than $2 \mathrm{~L} \mathrm{~kg}^{-1} \mathrm{~d}^{-1}$ with trace nutrient supplementation. ("Low solids" is here defined as a digesting slurry that has free drainable liquid.) It has been suggested that trace nutrient additions are likely to be required for stable digestion of biomass. ${ }^{9}$ Four napiergrass digesters operated at a low loading rate saw a marked reduction in volatilc fatty acid (VFA) concentrations and a corresponding increase in biogas production when trace quantities of nickel, cobalt, molybdenum, selenium and sulfur were added. ${ }^{10}$

Sorghum (Sorghum bicolor L. Moench) has been identified as a potential "energy crop" due to high yields and biodegradability. " Field corn (Zea mays L.) has comparable cultural requirements and dry matter yields ${ }^{3}$ in New York State, but yields of corn are somewhat more reliable, since sorghum is sensitive to the state's relatively cool climate. ${ }^{12}$

\section{MATERIALS AND METHODS}

\subsection{Substrate analysis}

Sorghum (commercial hybrid silage variety X9204, Stanford Seeds) was grown at Cornell 
University in 1987. The entire aboveground250portion of the plant was fieldchopped after maturity and ensiled at $30-40 \%$ TS by sealing it in a large plastic bale bag at room temperature. Corn (an unknown commercial field corn variety with 85-105 days maturity) was grown at Cornell University in 1989. As with sorghum, the entire plant (including grain) was field-chopped after maturity and ensiled in a large bunker silo. Both crops were grown and harvested using conventional cultural practices. The resulting ensiled materials were later air-dried at $55^{\circ} \mathrm{C}$ to over $90 \%$ TS to prevent spoilage during handling, and were hammermilled to fracture seeds and to reduce particle sizes to less than $0.5 \mathrm{~cm}$. All solids analysis and kinetics were based on the composition of the materials after drying and milling. For one condition, sorghum and alpha-cellulose (Sigma Chemical) were mixed 1:1 on a VS basis to adjust the $\mathrm{C}: \mathrm{N}$ ratio.

Fiber and in vitro analyses were conducted using the methods of Van Soest and Robertson ${ }^{13}$ and Robertson and Van Soest. ${ }^{14}$ The standard $48 \mathrm{~h}$ in vitro digestibility test was extended to $96 \mathrm{~h}$ to better approximate ultimate biodegradabilities. Biochemical methane potential (BMP) assays were carried out using a modified procedure of Owen et al. ${ }^{15}$ Elemental analysis was carried out by inductively-coupled plasma (ICP) emission spectroscopy, and carbon/ hydrogen/oxygen analysis was performed by Galbraith Laboratories (Knoxville, TN).

\subsection{Digester operation}

Digesters were operated as thermophilic $\left(55^{\circ} \mathrm{C}\right)$ semi-continuously fed-and-mixed systems, with feed added and effluent removed three times per week. Digesters were $10 \mathrm{~L}$ widemouth polypropylene carboys, operated with constant net contents of $5 \mathrm{~kg}$ (sorghum digesters, Conditions 1 through 4 ) or $3 \mathrm{~kg}$ (corn digesters, Conditions 5 and 6). Digester solids contents were maintained between 8 and $12 \%$ TS throughout the study.

A dry material feeder (AccuRate Inc. Model 300 with custom $1^{\prime \prime}$ helix) was used for the highest loading rate corn condition (Condition 6). Its purpose was to ameliorate the shock that results from the instantaneous addition of several days' feed, rather than to achieve a true continuous feeding regime. As such, the feeder was operated $1 \mathrm{~min} \mathrm{~h}^{-1}$ (concurrent with mixing) at a rate such that all feed for a two or three day interval was added by $18-24 \mathrm{~h}$ before the next sampling. This was done to optimize conversion efficiency by ensuring that all feed particles had at least an $18 \mathrm{~h}$ residence time.

A nitrogen gas purge was used to prevent air from entering the reactors during feeding and wasting. (It is unlikely that this technique totally excluded oxygen from the reactor headspace.) Digesters were mounted on a shaker table and mixed (approximately $100 \mathrm{rpm}, 1$ inch orbit) for $5 \mathrm{~min} \mathrm{~h}^{-1}(10 \mathrm{~min}$ for the highest loading rate corn condition), as well as manually before effluent removal and after addition of feed. This mixing regime was observed to result in complete mixing of digester contents. Tap water was added as part of the influent to control digester solids concentration. For the corn conditions, screened (\#16 sieve, $1.2 \mathrm{~mm}$ openings) liquid separated from stored digester effluents was used in place of tap water. This was done to reduce the need for supplementation of ammonia- $\mathrm{N}$ and other nutrients. Trace nutrients (from soluble salts) were supplemented at rates shown in Table 1. No attempt was made to optimize these addition rates other than to ensure that reactor concentrations of added elements remained in the general ranges which accompanied stable performance in previous high solids digesters. ${ }^{8}$ Addition rates were generally proportional to the OLR, with rates

Table 1. Trace nutrient elemental addition rates $\left(\mathrm{mg} \mathrm{kg}^{-1} \mathrm{~d}^{-1}\right)$ and source compounds

\begin{tabular}{|c|c|c|c|c|c|c|}
\hline \multirow[b]{2}{*}{ Element } & \multirow[b]{2}{*}{ I } & \multicolumn{3}{|c|}{ Conditions } & \multirow[b]{2}{*}{6} & \multirow[b]{2}{*}{ Source } \\
\hline & & 2 and 3 & 4 & 5 & & \\
\hline $\mathrm{Ni}$ & - & 1.50 & 2.10 & 0.90 & 3.50 & $\mathrm{NiSO}_{4} \cdot 6 \mathrm{H}_{2} \mathrm{O}$ \\
\hline Co & - & 1.00 & 1.40 & 0.50 & 1.95 & $\mathrm{CoCl}_{2} \cdot 6 \mathrm{H}_{2} \mathrm{O}$ \\
\hline Mo & - & 1.25 & 1.75 & 0.63 & 2.44 & $\mathrm{NaMoO}_{2} \cdot 2 \mathrm{H}_{2} \mathrm{O}$ \\
\hline W & - & 0.20 & 0.30 & 0.10 & 0.39 & $\mathrm{Na}_{2} \mathrm{WO}_{4} \cdot 2 \mathrm{H}_{2} \mathrm{O}$ \\
\hline $\mathbf{S}$ & - & 5.0 & 7.0 & 2.4 & 9.5 & $\mathrm{~K}_{2} \mathrm{SO}_{4}$ \\
\hline $\mathrm{Cu}$ & - & - & - & 0.001 & 0.004 & $\mathrm{CuSO}_{4} \cdot 5 \mathrm{H}_{2} \mathrm{O}$ \\
\hline V & - & - & - & 0.002 & 0.006 & $\mathrm{NH}_{4} \mathrm{VO}_{3}$ \\
\hline $\mathrm{Zn}$ & - & - & - & 0.12 & 0.45 & $\mathrm{ZnSO}_{4} \cdot 7 \mathrm{H}_{2} \mathrm{O}$ \\
\hline B & - & - & - & 0.003 & 0.013 & $\mathrm{H}_{3} \mathrm{BO}_{3}$ \\
\hline Mn & - & - & - & 0.005 & 0.020 & $\mathrm{MnSO}_{4} \cdot \mathrm{H}_{2} \mathrm{O}$ \\
\hline
\end{tabular}


lowered somewhat for corn (Conditions 5 and 6) due to the recycling of screened liquid. Due to the low VS loading rate and high background concentrations of trace elements resulting from the initial inoculum (well-digested sorghum), no trace nutrient additions were required for Condition 1. No base or buffer additions were made to any condition. In general, operating conditions were chosen to provide, if possible, a "safe excess" of environmental factors to allow maximum reaction rates.

\subsection{Analysis procedures}

Laboratory procedures and methods for kinetic analysis are detailed elsehwere. ${ }^{8,16}$ Trace metal analysis was performed on acid extracts (using $\mathrm{HCl}$, extract $\mathrm{pH}<2$ ) of the effluent using ICP spectroscopy. The measured trace nutrient concentrations were thus viewed as a "minimum labile pool", including not only trace nutrients normally in solution but also those easily acidsolubilized. Concentrations and rates were expressed on a mass basis. Mass removals were determined both on the basis of reactor mass loss (corrected for evaporation) and by the mass of biogas produced. VS removals were determined by VS mass balance and by comparison with total mass removals corrected for water removed by hydrolysis. Retention times are reported as solids retention time (SRT, reactor mass divided by effluent rate). Also reported is the influent-based "hydraulic retention time", HRT $_{\mathrm{i}}$ (reactor mass divided by the total inflow rate), which defines the total wet mass loading rate, not the actual residence time of material in the reactor. ${ }^{16}$

Gas volumes were measured with a wet gas meter. The pattern of biogas production during feeding intervals was recorded by connecting an event recorder (Esterline-Angus EventGraph) to the wet gas meter. Biogas volumes were standardized as dry biogas at $0^{\circ} \mathrm{C}$ and one atmosphere pressure. Effluent from several conditions was subjected to fiber analysis, as detailed above.

\section{RESULTS}

\subsection{Substrate composition}

Results of elemental analysis are presented in Table 2. The values for the sorghum/alphacellulose mix are calculated from component results (alpha-cellulose analysis is presented elsewhere $\left.e^{8}\right)$. Empirical formulae were calculated from the respective CHON contents, using a common carbon coefficient of 6 . Fiber and digestibility analyses are shown in Table 3. Data shown for the sorghum/alpha-cellulose mix

Table 2. Solids and elemental analysis of sorghum, sorghum/alpha-cellulose mix (calculated from components, solids confirmed by analysis) and corn

\begin{tabular}{lccc}
\hline & Sorghum & Mix & Corn \\
\hline Total solids, \% & 94.5 & 95.0 & 95.1 \\
Ash, \% of TS & 5.80 & 2.99 & 2.51 \\
VS, \% of TS & 94.2 & 97.0 & 97.5 \\
Per cent of TS: & & & \\
C & 46.3 & 45.3 & 47.2 \\
$\mathrm{H}$ & 6.17 & 6.36 & 6.40 \\
$\mathrm{O}$ & 38.1 & 43.2 & 41.4 \\
$\mathrm{~N}$ & 1.32 & 0.68 & 1.16 \\
$\mathrm{~K}$ & 2.10 & 1.08 & 0.72 \\
$\mathrm{P}$ & 0.272 & 0.140 & 0.23 \\
$\mathrm{Ca}$ & 0.297 & 0.164 & 0.17 \\
$\mathrm{Mg}$ & 0.235 & 0.121 & 0.23 \\
$\mathrm{~S}$ & 0.124 & 0.066 & 0.11 \\
$\mathrm{C} / \mathrm{N}$ ratio & 35.1 & 66.6 & 40.6 \\
$\mathrm{C} / \mathrm{P}$ ratio & 170 & 324 & 205 \\
Empirical formulae & $\mathrm{C}_{6} \mathrm{H}_{9.6} \mathrm{O}_{3.9} \mathrm{~N}_{0.15}$ & $\mathrm{C}_{6} \mathrm{H}_{10.1} \mathrm{O}_{4.3} \mathrm{~N}_{0.08}$ & $\mathrm{C}_{6} \mathrm{H}_{9.8} \mathrm{O}_{4.0} \mathrm{~N}_{0.13}$ \\
Parts per million (PPM) of TS: & & & 133 \\
$\mathrm{Fe}$ & 244 & 130 & 16.4 \\
$\mathrm{Na}$ & 18.0 & 230 & 18.7 \\
$\mathrm{Zn}$ & 29.8 & 15.6 & 10.5 \\
$\mathrm{Mn}$ & 18.9 & 9.82 & 11.6 \\
$\mathrm{Cu}$ & 5.68 & 2.99 & 1.95 \\
$\mathrm{~B}$ & 4.71 & 2.46 & 0.13 \\
$\mathrm{Mo}$ & 0.66 & 0.34 & 0.15 \\
$\mathrm{Co}$ & 0.16 & 0.08 & 0.00 \\
$\mathrm{Cd}$ & 0.12 & 0.06 & 0.00 \\
$\mathrm{Cr}$ & 0.73 & 0.38 & 0.10 \\
$\mathrm{Ni}$ & 0.44 & 0.31 & 0.01 \\
V & 0.17 & 0.12 & \\
\hline
\end{tabular}


Table 3. Substrate fiber and digestibility analysis

\begin{tabular}{lccc}
\hline \multicolumn{1}{c}{ Substrate } & Sorghum & Mix & Corn \\
\hline Neutral detergent fiber analysis, \% of VS: & & & \\
$\quad$ Cell solubles & 45.9 & 24.8 & 54.2 \\
Hemicellulose & 18.8 & 10.0 & 21.0 \\
Cellulose & 27.3 & 60.8 & 22.0 \\
Crude Lignin & 7.95 & 4.36 & 2.74 \\
$\quad$ Lignin & 3.57 & 1.69 & 1.48 \\
$\quad$ Cutin & 4.38 & 2.67 & 1.25 \\
In vitro digestibility, \% of vS & 79.1 & 87.6 & 87.4 \\
BMP Assay & & & \\
Methane potential, $\mathrm{Lg}^{-1}$ VS & 0.36 & 0.38 & $\mathrm{NA}$ \\
VS destruction, \% & 82.0 & 90.7 & 91.8 \\
\hline
\end{tabular}

were the results of direct analysis, except as noted below. Sorghum had a large cell soluble component ( $46 \%$ of VS), and a crude lignin content of nearly $8 \%$, divided equally between lignin (as determined by permanganate) and cutin. The cellulose content of the sorghum/alpha-cellulose mix was $60 \%$, with nearly $25 \%$ cell solubles. Corn had the highest cell soluble content $(54.2 \%)$ and the lowest crude lignin content $(2.7 \%)$ of any of the feedstocks. In vitro digestibilities $(96 \mathrm{~h})$ were uniformly lower than the digestibilities determined by the much longer BMP analysis. Volatile solids destruction as measured during BMP analysis were $82 \%$ for sorghum and $91.8 \%$ for corn. Due to an abnormally large variability in replicates, the measured $90.5 \%$ VS destruction for the sorghum/alpha-cellulose mix was not used. Instead, values were calculated from mix component data, resulting in a methane poten- tial of $0.38 \mathrm{~L} \mathrm{gVS}^{-1}$ and a nearly-identical VS destruction of $90.7 \%$.

\subsection{Sorghum and sorghum/alpha-cellulose di- gester operation}

Steady performance results for sorghum and sorghum/alpha-cellulose mix digester conditions are shown in Tables 4 and 5. Sorghum alone as a feedstock operated in a stable manner at a conventional organic loading rate (OLR) of $3.9 \mathrm{gVS} \mathrm{kg}^{-1} \mathrm{~d}^{-1}$ (Condition 1, Fig. 1), with a 70.2 day SRT. Methane production was stable at $1.33 \mathrm{~L} \mathrm{~kg}^{-1} \mathrm{~d}^{-1}$, with a methane yield of $0.34 \mathrm{~L} \mathrm{gVS}^{-1}$, which was $93.7 \%$ of sorghum's BMP. The mean mass removal rate was $3.19 \mathrm{~g} \mathrm{~kg}^{-1} \mathrm{~d}^{-1}$, with a VS removal rate of $2.85 \mathrm{gVS} \mathrm{kg}^{-1} \mathrm{~d}^{-1}$, indicating $0.109 \mathrm{~g}$ water consumed by hydrolysis per gram mass removed. The efficiency of VS conversion and removal was $72.4 \%$. Despite stability of all other indices,

Table 4. Steady performance period results for sorghum (Conditions 1, 3 and 4) and sorghum/alpha-cellulose mix (Condition 2) (standard deviation in parentheses)

\begin{tabular}{|c|c|c|c|c|}
\hline Condition & 1 & 2 & 3 & 4 \\
\hline Days operated continuously at OLR & 97 & 72 & 86 & 72 \\
\hline Number of SRTs operated & 1.4 & 2.0 & 3.2 & 4.3 \\
\hline Analysis period, day \#s & $78-97$ & $37-72$ & $135-158$ & $54-79$ \\
\hline Length of analysis period, days & 19 & 35 & 23 & 25 \\
\hline VS OLR (gVS kg-1 $\left.\mathrm{d}^{-1}\right)$ & 3.93 & 7.76 & 7.93 & 12.2 \\
\hline HRT $_{\text {i }}$ (influent-based, days) & 57.6 & 28.9 & 23.4 & 14.8 \\
\hline SRT (days) & 70.2 & 35.9 & 26.6 & 16.7 \\
\hline Biogas production $\left(\mathrm{L} \mathrm{kg}^{-1} \mathrm{~d}^{-1}\right)$ & $2.48(0.17)$ & $5.26(0.53)$ & $4.17(0.13)$ & $6.15(0.26)$ \\
\hline Methane production ( $\mathrm{L} \mathrm{kg}^{-1} \mathrm{~d}^{-1}$ ) & $1.33(0.09)$ & $2.73(0.27)$ & $2.25(0.07)$ & $3.26(0.14)$ \\
\hline Methane content $(\%)$ & 53.4 & 52.0 & 54.0 & 53.0 \\
\hline Methane yield ( $\mathrm{LVVS}^{-1}$ ) & 0.34 & 0.35 & 0.28 & 0.27 \\
\hline Methane yield ( $\%$ of BMP) & 93.7 & 92.7 & 77.5 & 74.1 \\
\hline \multicolumn{5}{|l|}{ Mass removal rate } \\
\hline Mass loss basis $\left(\mathrm{g} \mathrm{kg}^{-1} \mathrm{~d}^{-1}\right)$ & $3.21(0.21)$ & $6.85(0.64)$ & $5.49(0.17)$ & $7.98(0.32)$ \\
\hline Biogas basis $\left(\mathrm{g} \mathrm{kg}^{-1} \mathrm{~d}^{-1}\right)$ & $3.18(0.19)$ & $6.90(0.58)$ & $5.37(0.17)$ & $8.00(0.34)$ \\
\hline Mean $\left(\mathrm{g} \mathrm{kg}^{-1} \mathrm{~d}^{-1}\right)$ & 3.19 & 6.88 & 5.43 & 7.99 \\
\hline VS removal rate (gVS kg-1 $\mathrm{d}^{-1}$ ) & $2.85(0.10)$ & $5.93(0.67)$ & $4.98(0.20)$ & $7.27(0.41)$ \\
\hline VS removal efficiency $(\%)$ & 72.4 & 76.4 & 62.8 & 59.5 \\
\hline Hydrolysis (gwater g mass removed ${ }^{-1}$ ) & 0.109 & 0.137 & 0.083 & 0.090 \\
\hline BVS OLR (g BVS kg-1 $\left.\mathrm{d}^{-1}\right)$ & 3.23 & 7.04 & 6.50 & 10.0 \\
\hline So ( $g$ BVS $g$ influent ${ }^{-1}$ ) & 0.186 & 0.204 & 0.152 & 0.148 \\
\hline Se (g BVS g effluent ${ }^{-1}$ ) & 0.027 & 0.040 & 0.041 & 0.046 \\
\hline First order $k\left(d^{-1}\right)$ & 0.11 & 0.15 & 0.12 & 0.16 \\
\hline
\end{tabular}


Table 5. Steady performance period effluent analysis for sorghum (Conditions 1, 3 and 4) and sorghum/alphacellulose mix (Condition 2)

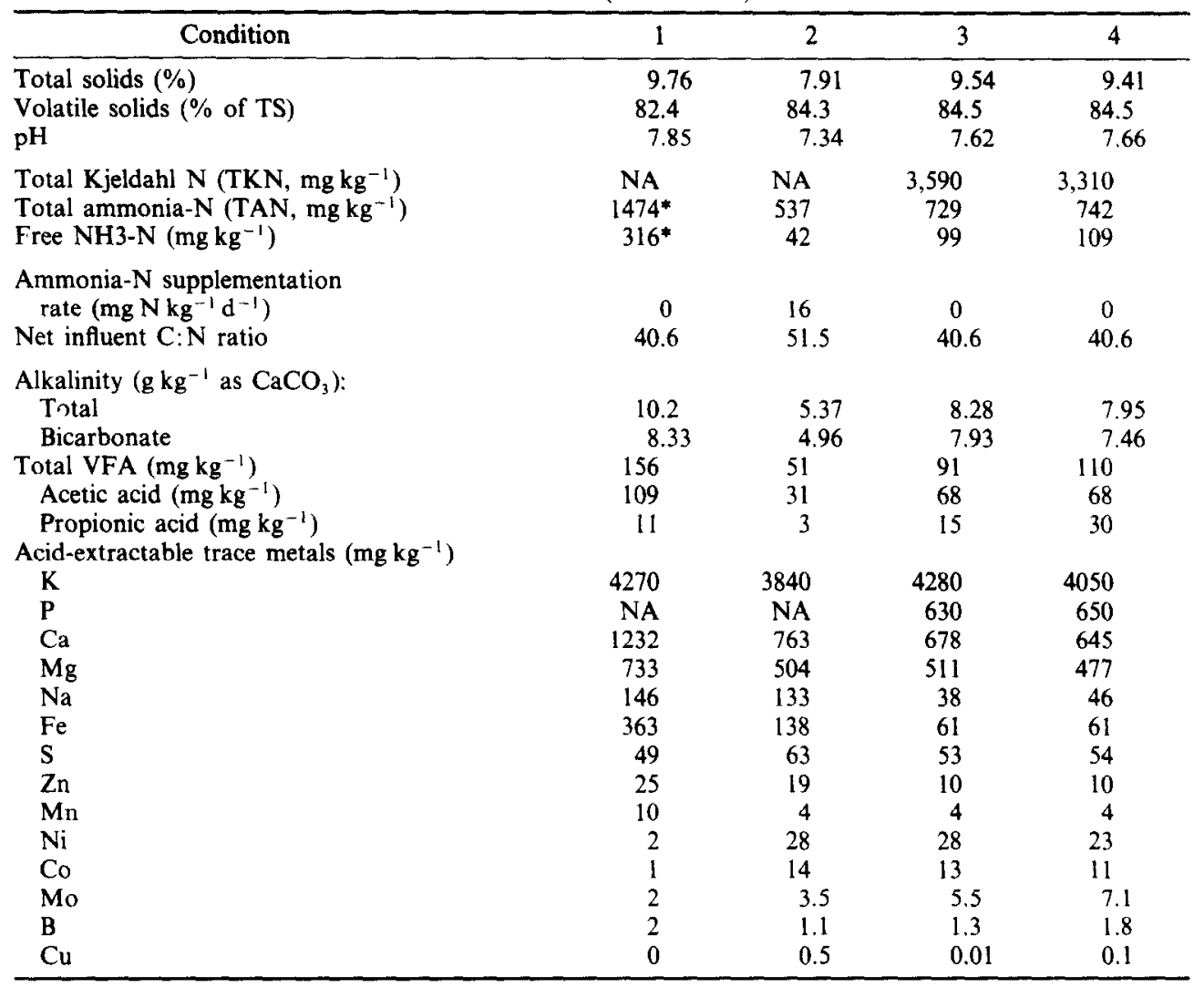

*Ammonia-N increasing, final values shown.

total ammonia-N (TAN) continually accumulated, reaching $1,500 \mathrm{mg} \mathrm{kg}^{-1}$ (Fig. 1). The rate of accumulation during steady performance was $8.4 \mathrm{mgTAN} \mathrm{kg}^{-1} \mathrm{~d}^{-1}$. The condition was terminated to preclude further accumulation and possible ammonia toxicity. Trace nutrient concentrations steadily declined from their high initial levels, but remained at detectable levels throughout the analysis period (Table 5).
To prevent TAN accumulations in condition 2 , sorghum/alpha-cellulose mix was used as the feedstock, and the OLR was increased to $7.76 \mathrm{gVS} \mathrm{kg}^{-1} \mathrm{~d}^{-1}$. Trace nutrient additions were begun. Operation was again stable: the noticeable period-to-period variation in removals (Fig. 2) tended to reflect the thriceweekly feeding pattern, as was observed in high solids systems fed the same feedstock. ${ }^{8}$

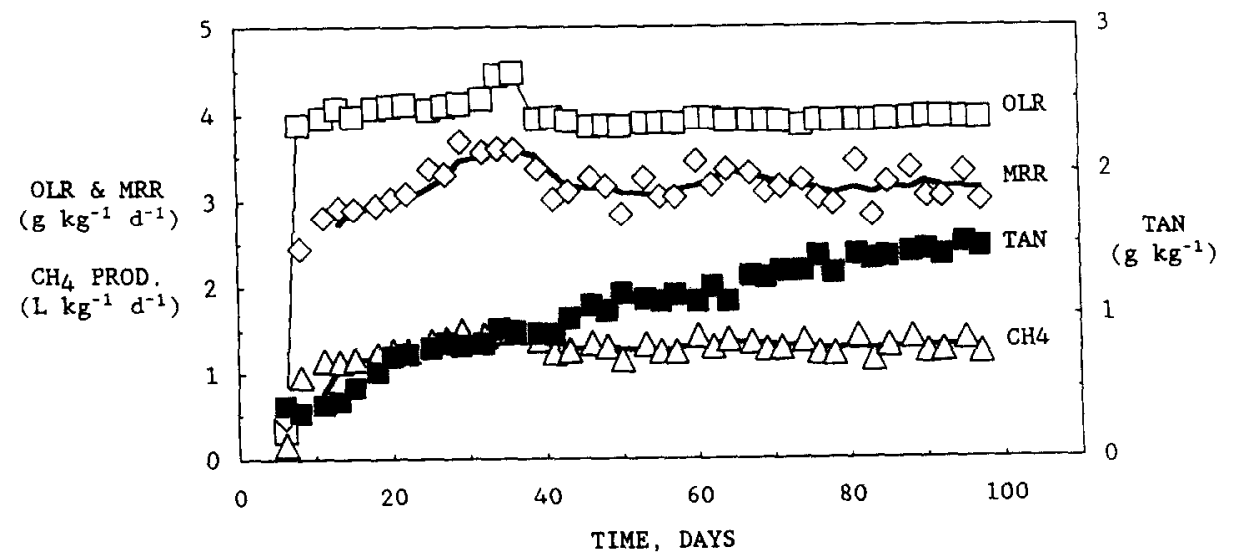

Fig. 1. Condition 1 (sorghum) operation. Organic loading rate (OLR), mass removal rate (MRR), methane production rate $\left(\mathrm{CH}_{4}\right)$, and effluent total ammonia- $\mathrm{N}$ concentration (TAN). Bold lines indicate weekly running means. 


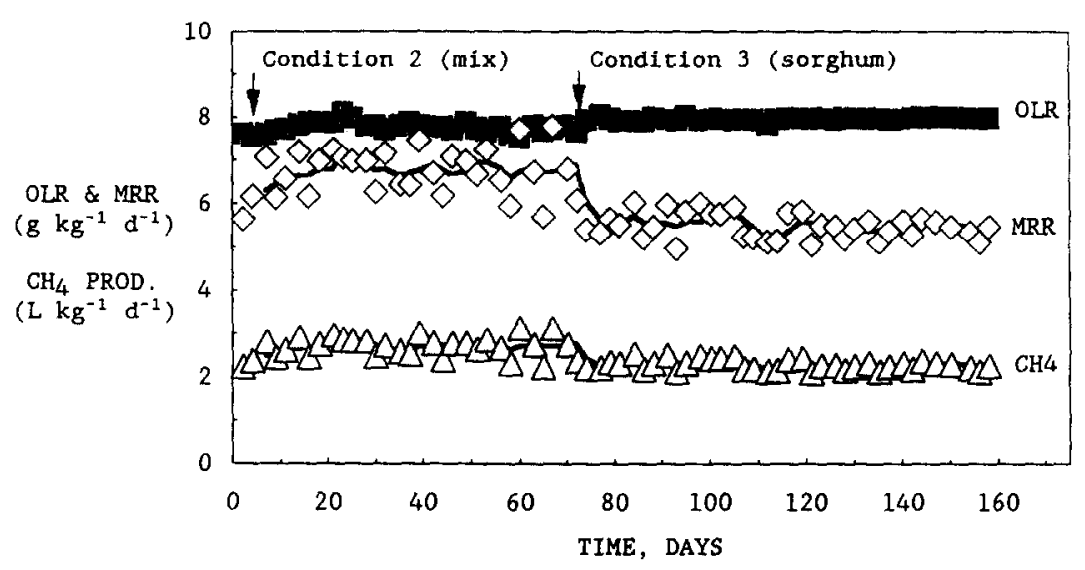

Fig. 2. Condition 2 (mix) and 3 (sorghum) operation. Same key as Fig. 1.

One-week running means show that the overall operation was stable. The mean methane production rate was $2.73 \mathrm{~L} \mathrm{~kg}^{-1} \mathrm{~d}^{-1}$, with a methane yield of $0.35 \mathrm{~L} \mathrm{gVS}^{-1}$. The mean mass removal rate was $6.88 \mathrm{~g} \mathrm{~kg}^{-1} \mathrm{~d}^{-1}$. The VS removal rate was $5.93 \mathrm{gVS} \mathrm{kg}^{-1} \mathrm{~d}^{-1}$, yielding a VS removal efficiency of $76.4 \%$. Mean total VFAs were only $51 \mathrm{mg} \mathrm{kg}^{-1}$, indicating very stable operation. Ammonia-N (as $\mathrm{NH}_{4} \mathrm{Cl}$ ) eventually had to be supplemented at a constant rate of $16 \mathrm{mgN} \mathrm{kg}^{-1} \mathrm{~d}^{-1}$ to maintain an average effluent TAN concentration of $537 \mathrm{mg} \mathrm{kg}^{-1}$. The $N$ addition resulted in a net influent $C: N$ ratio of 51.5.

Pure sorghum feedstock was then used at an OLR of $7.93 \mathrm{gVS} \mathrm{kg}^{-1} \mathrm{~d}^{-1}$ for Condition 3 (Fig. 2). The shorter SRT (26.6 days) resulted in acceptable equilibrium TAN concentrations of $729 \mathrm{mgN} \mathrm{kg}{ }^{-1}$. The mass removal rate stabilized at $5.43 \mathrm{~g} \mathrm{~kg}^{-1} \mathrm{~d}^{-1}$, lower than in Condition 2 due to the lower biodegradability of the sorghum alone. Similarly, the VS removal efficiency of $62.8 \%$ was also lower. Mean total VFAs were $91 \mathrm{mg} \mathrm{kg}^{-1}$.
Due to the stability of Condition 2, a second digester was started to operate concurrently using sorghum loaded at a rate of $12.2 \mathrm{gVS} \mathrm{kg}^{-1} \mathrm{~d}^{-1}$ and an SRT of 16.7 days (Condition 4). This digester also operated in an extremely stable manner (Fig. 3), producing methane at $3.26 \mathrm{~L} \mathrm{~kg}^{-1} \mathrm{~d}^{-1}$, with a methane yield of $0.27 \mathrm{LgVS}^{-1}$. The mean mass removal was $7.99 \mathrm{~g} \mathrm{~kg}^{-1} \mathrm{~d}^{-1}$, with a VS removal rate of $7.27 \mathrm{gVS} \mathrm{kg}^{-1} \mathrm{~d}^{-1}$. The VS removal efficiency was $59.5 \%$. Mean VFAs were $110 \mathrm{mg} \mathrm{kg}^{-1}$, and TAN concentrations averaged $742 \mathrm{mgN} \mathrm{kg}^{-1}$.

For Conditions 1 through 4 conventionallydefined "retention times", $\mathrm{HRT}_{\mathrm{i}}$ (reactor mass divided by the total mass inflow rate), were shorter than the actual retention times (SRT) due to the removal of a significant fraction of the total influent mass of biogass. SRT/HRT ratios ranged from 1.13 to 1.22 (sorghum conditions) to 1.24 (sorghum/alpha/cellulose mix).

\subsection{Corn digester operation}

Condition 5 (Fig. 4) was operated with corn at an OLR of $8.25 \mathrm{gVS} \mathrm{kg}^{-1} \mathrm{~d}^{-1}$ with a SRT of

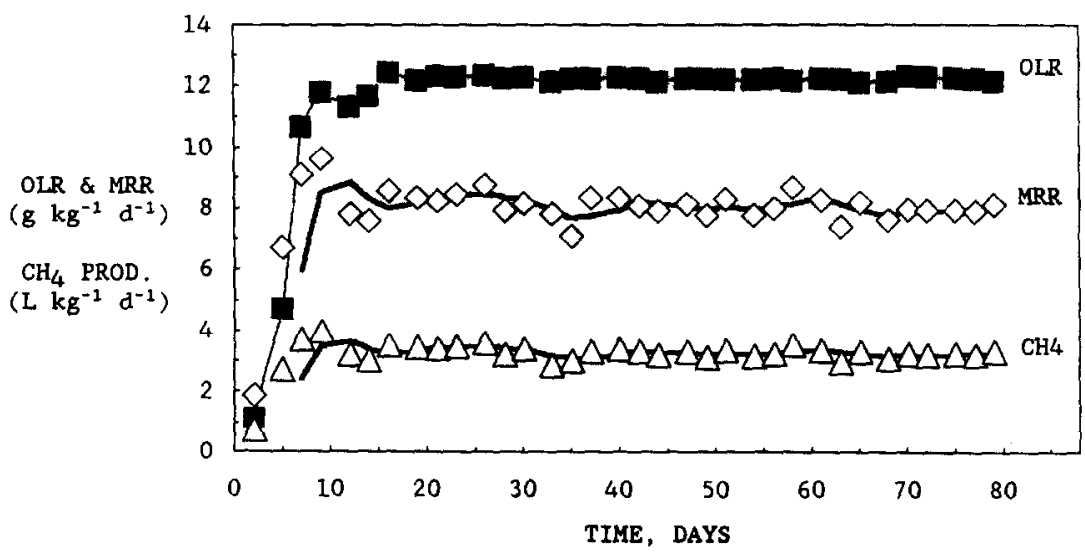

Fig. 3. Condition 4 (sorghum) operation. Same key as Fig. 1. 


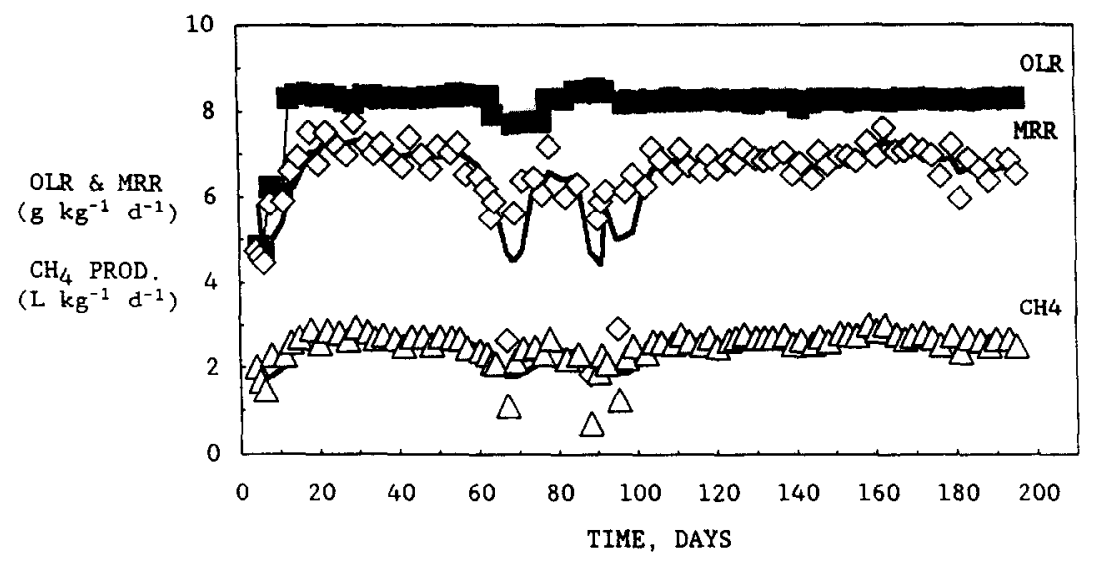

Fig. 4. Condition 5 (corn) operation. Same key as Fig. 1.

30.9 days, and appeared stable until day 60 , when VFA (primarily propionic acid) began to rapidly accumulate, reaching $2 \mathrm{~g} \mathrm{~kg}^{-1}$ total VFA. Additions of recycled liquids were begun at the rate of $10 \mathrm{~mL} \mathrm{~kg}^{-1} \mathrm{~d}^{-1}$ to help prevent possible shortages of limiting nutrients as well as to increase TAN concentrations. The system recovered, consuming all excess VFA in a single feeding interval. An attempts on day 78 to extend the feeding interval to 4 days (thereby increasing the instantaneous loading rate) triggered a second period of VFA accumulation, again primarily propionate. Excess VFAs were only gradually removed as feedings were resumed. Operation thereafter was stable, with a mean methane production rate of $2.69 \mathrm{~L} \mathrm{~kg}^{-1} \mathrm{~d}^{-1}$ and a methane yield of $0.326 \mathrm{~L} \mathrm{gVS}^{-1}$ (Tables 6 and 7). The mass removal rate was $6.87 \mathrm{~g} \mathrm{~kg}^{-1} \mathrm{~d}^{-1}$, and the VS removal rate was $5.87 \mathrm{gVS} \mathrm{kg}^{-1} \mathrm{~d}^{-1}$, yielding a hydrolysis coefficient of $0.146 \mathrm{~g} \mathrm{H}_{2} \mathrm{O}$ hydrolytically consumed per gram mass removed. The VS removal efficiency was $71.2 \%$. Mean VFAs were $167 \mathrm{mg} \mathrm{kg}^{-1}$.

A range of higher loading rates were attempted with the continuous feeder. Operation

Table 6. Corn semicontinuous (Condition 5) and continuous (Condition 6) steady performance period results (standard deviation in parentheses)

\begin{tabular}{|c|c|c|}
\hline Condition & 5 & 6 \\
\hline Days operated continuously at OLR & 195 & 67 \\
\hline Number of SRTs operated & 6.3 & 5.0 \\
\hline Analysis period, days & $111-195$ & $39-67$ \\
\hline Length of analysis period, days & 84 & 28 \\
\hline Recycle rate $\left(\mathrm{mL} \mathrm{kg}^{-1} \mathrm{~d}^{-1}\right)$ & 10.0 & 50.9 \\
\hline Recycled TS (gTS kg ${ }^{-1} \mathrm{~d}^{-1}$ ) & 0.39 & 1.19 \\
\hline Recycled VS (gVS kg ${ }^{-1} \mathrm{~d}^{-1}$ ) & 0.29 & 0.92 \\
\hline Recycled TAN (mgN kg-1 $\left.\mathrm{d}^{-1}\right)$ & 9.8 & 48.6 \\
\hline Recycled TKN (mgN kg $\left.{ }^{-1} \mathrm{~d}^{-1}\right)$ & NA & 154 \\
\hline VS OLR ( $\left(\mathrm{gVS} \mathrm{kg}^{-1} \mathrm{~d}^{-1}\right)$ & 8.25 & 18.1 \\
\hline HRT $_{i}$ (influent-based, days) & 25.5 & 11.1 \\
\hline SRT (days) & 30.9 & 13.2 \\
\hline Biogas production $\left(\mathrm{L} \mathrm{kg}^{-1} \mathrm{~d}^{-1}\right)$ & $5.20(0.23)$ & $10.0(0.41)$ \\
\hline Biogas calculated from mass loss $\left(\mathrm{L} \mathrm{kg}^{-1} \mathrm{~d}^{-1}\right)$ & - & $10.6(0.38)$ \\
\hline Methane production $\left(\mathrm{L} \mathrm{kg}^{-1} \mathrm{~d}^{-1}\right)$ & $2.69(0.78)$ & $5.43(0.19)$ \\
\hline Methane content $(\%)$ & 51.8 & 51.8 \\
\hline Methane yield $\left(\mathrm{L} \mathrm{gVS}^{-1}\right)$ & 0.326 & 0.300 \\
\hline \multicolumn{3}{|l|}{ Mass removal rate } \\
\hline Mass loss basis $\left(\mathrm{g} \mathrm{kg}^{-1} \mathrm{~d}^{-1}\right)$ & $6.90(0.28)$ & $14.1(0.52)$ \\
\hline Biogas basis $\left(\mathrm{g} \mathrm{kg}^{-1} \mathrm{~d}^{-1}\right)$ & $6.84(0.31)$ & $13.3(0.56)$ \\
\hline Mean $\left(\mathrm{g} \mathrm{kg}^{-1} \mathrm{~d}^{-1}\right)$ & 6.87 & - \\
\hline VS removal rate $\left(\mathrm{gVS} \mathrm{kg}^{-1} \mathrm{~d}^{-1}\right)$ & $5.87(0.80)$ & $12.2(0.58)$ \\
\hline Hydrolysis (g water g mass removed ${ }^{-1}$ ) & 0.146 & 0.136 \\
\hline VS removal efficiency $(\%)$ & 71.2 & 67.4 \\
\hline BVS OLR (gBVS kg-1 $\mathrm{d}^{-1}$ ) & 7.57 & 16.6 \\
\hline So ( $\mathrm{g}$ BVS $\mathrm{g}$ influent $\mathrm{t}^{-1}$ ) & 0.193 & 0.184 \\
\hline Se (g BVS $g$ effluent ${ }^{-1}$ ) & 0.053 & 0.058 \\
\hline First order $k\left(d^{-1}\right)$ & 0.11 & 0.21 \\
\hline
\end{tabular}


Table 7. Corn semicontinuous (Condition 5) and continuous (Condition 6) steady performance period effluent analysis

\begin{tabular}{lcc}
\hline \multicolumn{1}{c}{ Condition } & 5 & 6 \\
\hline Total solids & 9.58 & 11.0 \\
Volatile solids (\% of TS) & 88.4 & 87.7 \\
$\mathrm{pH}$ & 7.32 & 7.44 \\
Total Kjeldahl N (TKN, $\left.\mathrm{mg} \mathrm{kg}^{-1}\right)$ & 3880 & 4900 \\
Total ammonia-N (TAN, $\left.\mathrm{mg} \mathrm{kg}^{-1}\right)$ & 418 & 735 \\
Free NH3-N $\left(\mathrm{mg} \mathrm{kg}^{-1}\right)$ & 31 & 70 \\
Total VFA (mg kg & 167 & 1250 \\
Acetic acid $\left(\mathrm{mg} \mathrm{kg}^{-1}\right)$ & 88 & 67 \\
Propionic acid $\left(\mathrm{mg} \mathrm{kg}^{-1}\right)$ & 28 & 1167 \\
Acid-extractable trace nutrients $\left(\mathrm{mg} \mathrm{kg}^{-1}\right)$ & & \\
$\mathrm{K}$ & 3167 & 3670 \\
$\mathrm{P}$ & 798 & 700 \\
$\mathrm{Ca}$ & 721 & 845 \\
$\mathrm{Mg}$ & 939 & 959 \\
$\mathrm{Na}$ & 128 & 80 \\
$\mathrm{Fe}$ & 38.6 & 31 \\
$\mathrm{~S}$ & 77 & 88 \\
$\mathrm{Zn}$ & 14.2 & 13 \\
$\mathrm{Mn}$ & 3.6 & 4.7 \\
$\mathrm{Ni}$ & 26.4 & 33 \\
$\mathrm{Co}$ & 7.9 & 14 \\
$\mathrm{Mo}$ & 3.3 & 4.1 \\
$\mathrm{~B}$ & 1.2 & 1.2 \\
$\mathrm{Cu}$ & 0.5 & 0.6 \\
\hline
\end{tabular}

at an OLR of $21 \mathrm{gVS} \mathrm{kg}^{-1} \mathrm{~d}^{-1}$ with a SRT of 11 days resulted in a gradual reactor failure (data not shown). At a reduced loading rate of $18 \mathrm{gVS} \mathrm{kg}^{-1} \mathrm{~d}^{-1}$ with a 13.2 day SRT (Condition 6) the system operated in a stable manner (Fig. 5). Power was interrupted and feeder control stopped during days 33-35, drastically lowering the OLR for that interval. The VFA content fluctuated throughout the condition, but appeared to be self-controlling, with no outside intervention required. (The first decline in VFA content, accelerated by the drop in feed additions during days 33-35, began spontaneously 2 feedings earlier.) The mean VFA content for the period was $1,250 \mathrm{mg} / \mathrm{kg}$, predominantly propionate $(1,167 \mathrm{mg} / \mathrm{kg})$. The recycle rate of screened liquids for this condition was $50.9 \mathrm{~mL} \mathrm{~kg}^{-1} \mathrm{~d}^{-1}$, resulting in solids loading rates of $1.19 \mathrm{gTS} \mathrm{kg}^{-1} \mathrm{~d}^{-1}$ and $0.92 \mathrm{gVS} \mathrm{kg}^{-1} \mathrm{~d}^{-1}$. Nitrogen loading rates from the recycle were $48.6 \mathrm{mg} \mathrm{kg}^{-1} \mathrm{~d}^{-1}$ TAN and $154 \mathrm{mg} \mathrm{kg}^{-1} \mathrm{~d}^{-1} \mathrm{TKN}$.

A slow but consistent gas leak, eventually traced to the feeder system, was present during Condition 6 , as evidenced by the approximately $6 \%$ disparity in Table 6 between mass removal rates calculated from mass losses (14.1 $\left.\mathrm{g} \mathrm{kg}^{-1} \mathrm{~d}^{-1}\right)$ and from measured biogas production $\left(13.3 \mathrm{~g} \mathrm{~kg}^{-1} \mathrm{~d}^{-1}\right)$. Total gas production, estimated by back-calculating from the mass-loss-based removal rate, was $10.6 \mathrm{~L} \mathrm{~kg}^{-1} \mathrm{~d}^{-1}$, resulting in a methane pro-

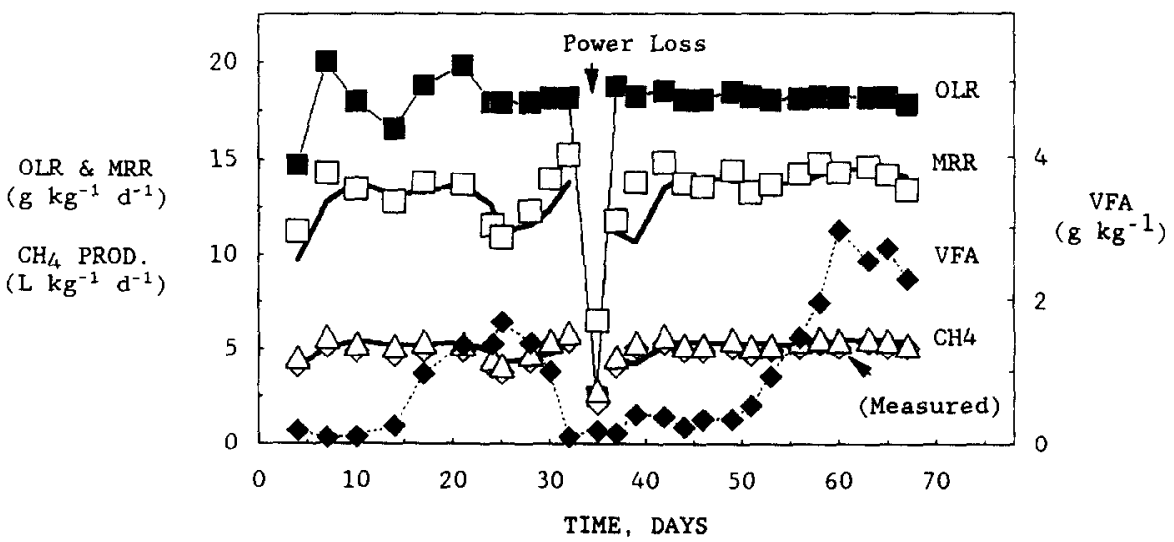

Fig. 5. Condition 6 (continuously-fed corn). Same key as Fig. 1, with measured (uncorrected) methane and total VFA. 


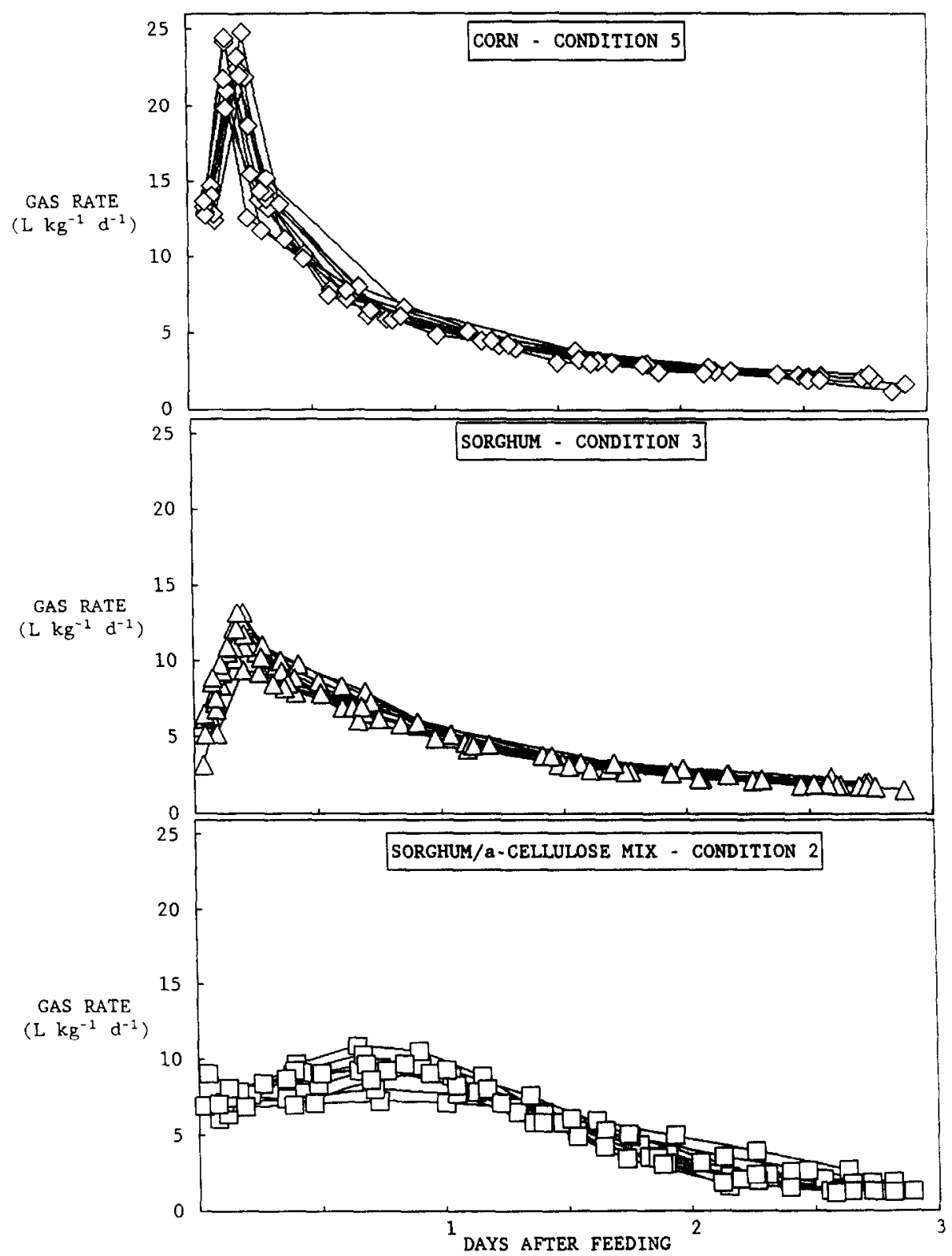

Fig. 6. Instantaneous biogas production rates following three-day feedings for corn, sorghum and sorghum/alpha-cellulose mix at similar OLRs.

duction rate of $5.43 \mathrm{~L} \mathrm{~kg}^{-1} \mathrm{~d}^{-1}$ and a methane yield of $0.30 \mathrm{~L} \mathrm{gVS}^{-1}$. Both measured and calculated methane production rates are shown in Fig. 5. The VS removal rate was stable at $12.2 \mathrm{gVS} \mathrm{kg}^{-1} \mathrm{~d}^{-1}$, resulting in a VS removal efficiency of $67.4 \%$ and a hydrolysis coefficient of $0.136 \mathrm{~g} \mathrm{H}_{2} \mathrm{O}$ per $\mathrm{g}$ mass removed. The agreement between the hydrolysis coefficients in Conditions 5 and 6 confirms the validity of the mass-loss based removal rate and the corrected gas production rate.

The mean solids content for the period $(11.0 \%)$ was affected by the accidental feeding rate reduction mentioned above, which oc- curred a week before steady performance began. By the end of the steady performance period the digester solids contents stabilized at $11.5 \%$ TS, more representative of the condition. The mean effluent TAN content was $735 \mathrm{mgN} \mathrm{kg}^{-1}$.

As with sorghum, conventionally-defined "retention times" $\left(\mathrm{HRT}_{i}\right)$ were shorter than the actual SRTs. SRT/HRT ${ }_{i}$ ratios were 1.21 for Conditions 5 and 1.18 for Condition 6 .

\subsection{First-order kinetics}

BMP VS destruction values were used as estimates of ultimate biodegradability, allowing calculation of influent (So) and effluent (Se) 


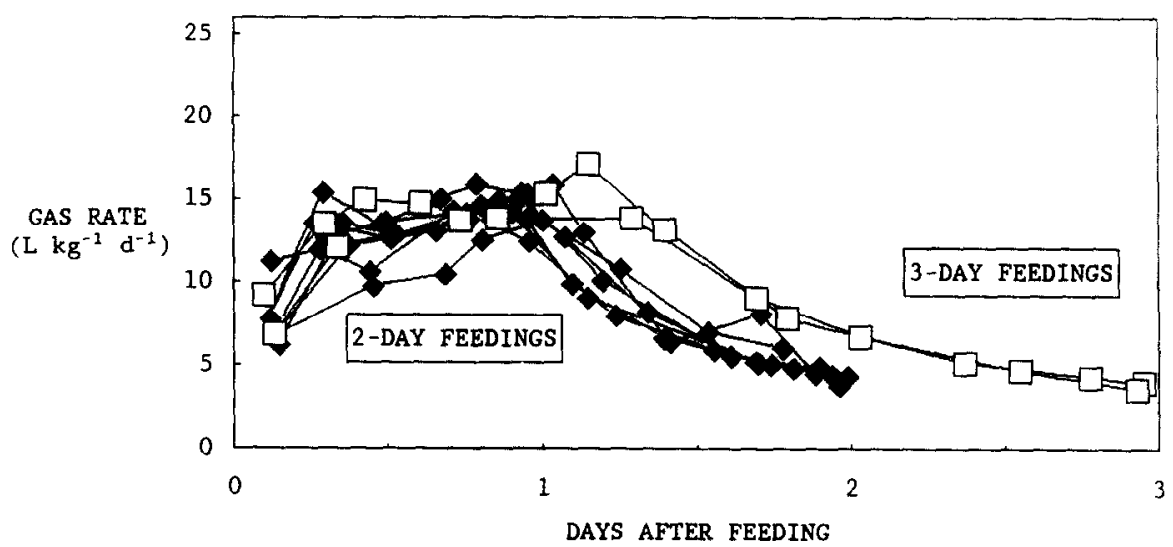

Fig. 7. Condition 6 instantaneous gas production rates for two-day and three-day continuous feeding intervals. (Three intervals not shown due to erratic feeder operation.)

biodegradable VS (BVS) concentrations and loading rates. BVS-based first order reaction rate coefficients (Tables 4 and 6 ) for semi-continuously fed conditions (all substrates) fell within a fairly narrow range of 0.11 to $0.16 \mathrm{~d}^{-1}$, with a rate coefficient of $0.21 \mathrm{~d}^{-1}$ for continuously-fed Condition 6.

\subsection{Instantaneous gas production rates}

Figure 6 compares instantaneous biogas production rates during 3-day feeding intervals for corn, sorghum and sorghum/alpha-cellulose mix feedstocks at similar loading rates of 7.76 to $8.25 \mathrm{~g} \mathrm{VS} \mathrm{kg}^{-1} \mathrm{~d}^{-1}$ (Conditions 2, 3 and 5). Rates peaked at approximately $5 \mathrm{~h}$ after feeding for corn and sorghum, with peak corn rates double those of sorghum. The mixed feedstock peak was lower, occurring approximately 16-20 h after feeding. Despite a much higher overall loading rate, the continuous feeding regime for condition 6 (Fig. 7) kept peak rates at or below about $15 \mathrm{~L} \mathrm{~kg}^{-1} \mathrm{~d}^{-1}$.

\subsection{Fiber component degradation}

Fiber component mass balances based on effluent fiber analysis were performed for Conditions 3, 4 and 5. Destruction efficiencies (Table 8) were expressed as $\%$ of initial cellulose and hemicellulose VS degraded. For sorghum, $67.9-70.8 \%$ of hemicellulose and $56.9 \%-61.6 \%$

Table 8. Fiber component destruction efficiencies for Conditions 3,4 and 5. Expressed as \% of initial fiber VS destroyed

\begin{tabular}{ccc}
\hline Condition & $\begin{array}{c}\text { Cellulose } \\
(\%)\end{array}$ & $\begin{array}{c}\text { Hemicellulose } \\
(\%)\end{array}$ \\
\hline 3-Sorghum & 70.8 & 61.6 \\
4-Sorghum & 67.9 & 56.9 \\
5-Corn & 77.3 & 67.1 \\
\hline
\end{tabular}

of cellulose were destroyed. For corn, $77.3 \%$ of hemicellulose and $67.1 \%$ of cellulose were destroyed.

\section{DISCUSSION}

The methane production rates presented here are among the highest reported for slurry digestion of naturally-occurring particulate biomass, and are significantly higher than those achievable under conventional operation (Fig. 8). The mode of reactor operation was extremely simple: Trace nutrients (as direct supplements alone or in concert with recycled liquids) plus hourly mixing allowed operation with sorghum at loading rates up to $12 \mathrm{gVS} \mathrm{kg}^{-1} \mathrm{~d}^{-1}$, resulting in methane production rates up to $3.3 \mathrm{~L} \mathrm{~kg}^{-1} \mathrm{~d}^{-1}$. Process stability was attested to by constant gas production rates and by low, stable VFA concentrations in all semicontinuously fed conditions. The inclusion of continuous feeding for Condition 6 allowed loading rates up to $18 \mathrm{gVS} \mathrm{kg}^{-1} \mathrm{~d}^{-1}$, with a methane production rate of $5.4 \mathrm{~L} \mathrm{~kg}^{-1} \mathrm{~d}^{-1}$. VFA concentrations were higher and more variable with the heavily-fed continuous-feed condition, but appeared to be self-regulating.

Methane production rates were directly related to loading rate (Fig. 8), with rates in the continuous corn unit (Condition 6) approaching those of high solids systems. ${ }^{8}$ VS conversion was efficient, reflecting high feedstock biodegradabilities. Removal efficiency was inversely related to SRT (Fig. 9), with, as expected, the more biodegradable feedstocks resulting in higher removal efficiencies at a given SRT. Even at the shortest SRTs and highest OLRs, the removal efficiency on a biodegradable (BVS) basis was over $73 \%$. 


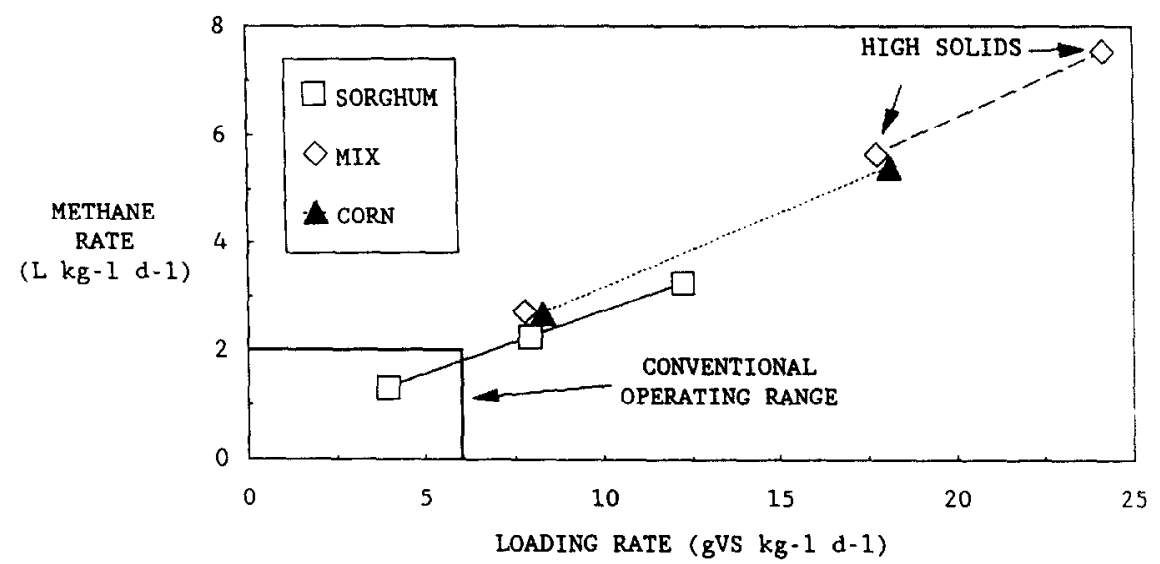

Fig. 8. Steady-performance methane production rate vs. organic loading rate (OLR). High solids data from Ref. 8.

The impact of feedstock milling on observed reaction rates and efficiencies was not quantified. However, it has been noted that, as a minimum measure, seed coats of grain contained in the feedstock should be fractured. Grain (in field-chopped silage) with intact seed coats has been observed to emerge from digestion unscathed, ${ }^{17}$ which creates the potential for significant reductions in both rates and efficiencies, since up to half of silage dry matter can be present in the grain fraction.

Peak instantaneous biogas production rates appeared directly related to substrate cell soluble content for semicontinuously-fed conditions. Corn, with a cell soluble content of nearly $55 \%$ of VS, had the highest peak rate. Instantaneous rates varied up to twelvefold over the course of a 3-day feeding interval for corn, nearly tenfold for sorghum and fivefold for the sorghum/alpha-cellulose mix. For both corn and sorghum, the bulk of conversion appeared to be completed two days after feeding, with instantaneous biogas production rates dropping below $2.5 \mathrm{~L} \mathrm{~kg}^{-1} \mathrm{~d}^{-1}$. Variation was greatly reduced under continuous feeding, with only a fivefold change in instantaneous rates for cornfed Condition 6.

TAN concentrations over 2 to $3 \mathrm{~g} \mathrm{~kg}^{-1}$ are considered inhibitory to non-adapted systems, especially where the $\mathrm{pH}$ is high enough to cause a significant fraction to be in the associated $\mathrm{NH}_{3}$ form. ${ }^{18}$ Sorghum's C: $\mathrm{N}$ ratio of 35 appeared to be too low for operation at extremely long SRTs (i.e. 70 days for condition 1), where cell die-off and accumulation of mineralized ammonia- $\mathrm{N}$ is favored. There was no accumulation problem at higher loading rates, where cycling is less efficient. Recycling of liquids met the $\mathbf{N}$ requirement posed by the higher $\mathrm{C}: \mathrm{N}$ ratio of corn.

The lowered VS removal efficiency at high loading rates (i.e. $67.4 \%$ for Condition $6,73.5 \%$ on a BVS basis) indicates potential for multistage operation, with second-stage digesters used to increase overall VS removals. Testing of

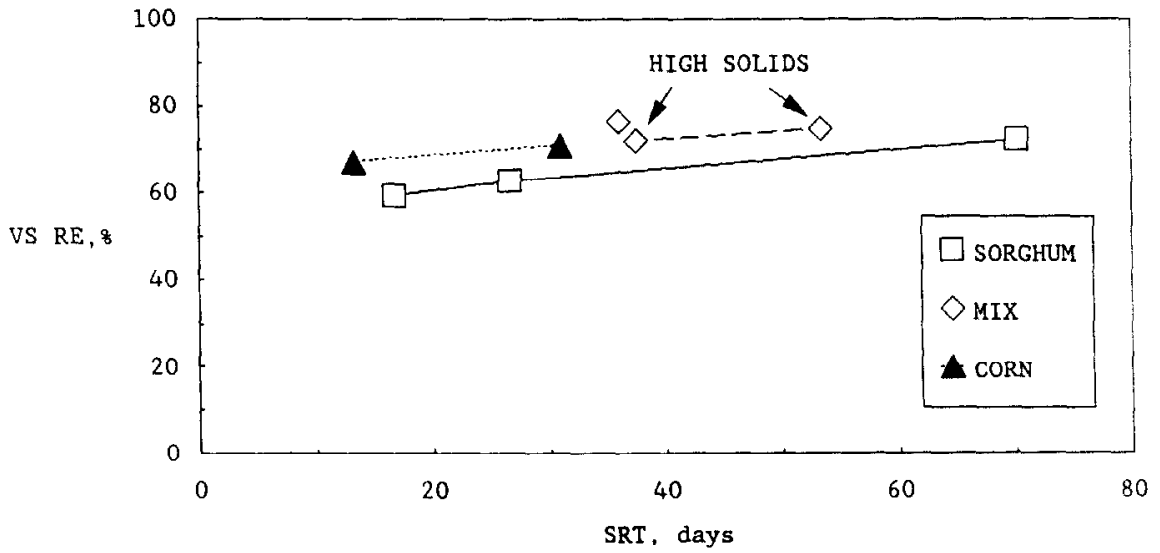

Fig. 9. Steady-performance VS removal efficiency (VS RE) vs. solids retention time (SRT). High solids data from Ref. 8. 
a second-stage solids-concentrating digester following the Condition 6 digester (data not shown) resulted in a net system methane production rate of $4.53 \mathrm{~L} \mathrm{~kg}^{-1} \mathrm{~d}^{-1}$, a slight decrease from the first stage alone. However, the overall VS removal efficiency was significantly enhanced, reaching $75.7 \%(82.5 \%$ on a BVS basis). ${ }^{19}$

This data indicates significant potential for simple, high rate slurry digestion of biomass. Further study is needed to optimize the form and degree of trace nutrient additions, and to define the effects of operating variables such as increased recycling of liquids, mixing, feedstock particle size, multi-stage operation and optimum timing of feed additions. Operation of semi-solid digesters at intermediate solids contents (i.e. between 12 and $20 \%$ TS) also warrants investigation.

Acknowledgements-- This research was carried out at Cornell University supported by the Gas Research Institute under GRI Contract No. 5088-260-1658, Dr Thomas D. Hayes, technical manager. BMP analysis was carried out by Mr Charles Turick, Mr John Owens and Dr David Chynoweth of the University of Florida. The authors gratefully acknowledge the assistance of Frederick G. Herndon, Timothy D. Nock, Warren C. Chrusciel, Dr Thomas E. White and Kent K. Bares.

\section{REFERENCES}

I. J. R. Frank and W. H. Smith, Perspectives on Biomass Research. In Methane From Biomass: A Systems Approach. (W. H. Smith and J. R. Frank, Eds), pp. 455-464. Elsevier Applied Science, New York (1987).

2. M. Takashima and R. E. Speece, Mineral nutrient requirements for high-rate methane fermentation of acetate at low SRT. Res. J. WPCF 61(11/12), 1645-1650 (1989).

3. W. J. Jewell, R. J. Cummings, A. M. Whitney, F. G. Herndon and B. K. Richards, Engineering Design Considerations for Methane Fermentation of Energy Crops. Cornell University 3rd Year Annual Report for the Gas Research Institute. GRI Report No. GRI-87/0061. Chicago, Illinois, 60631 (1987).

4. D. E. Jerger and D. P. Chynoweth, Anaerobic digestion of sorghum. Biomass 14, 99-113 (1987).

5. Srivastava, V. J., R. Biljetina, H. R. Isaacson and T. D. Hayes. Biogasification of Sorghum in a Novel Anaerobic Digester. Paper presented at the 42nd Purdue Industrial Waste Conference (May 12-14, 1987).
6. Ph. Marique, A. Gilles, F. Edeline and L. Joassin, Thermophilic semi-solid anaerobic digestion of municipal refuse. Biotechnol. Bioeng. 33, 536-541 (1989).

7. L. De Baere, O. Verdonck and W. Verstraete, High rate dry anaerobic fermentation for the organic fraction of solid waste. Biotechnol. Bioeng. Symp. 15, 321-330 (1985).

8. B. K. Richards, R. J. Cummings, W. J. Jewell and F. G. Herndun, High solids anaerobic methane fermentation of sorghum and cellulose. Biomass and Bioenergy 1, 47-53 (1991).

9. R. E. Speece, Nutrient requirements. In Anaerobic Digestion of Biomass (D. P. Chynoweth and R. H. Isaacson, Eds), pp. 109-128. Elsevier Applied Science, New York (1987).

10. A. Wilkie, M. Goto, F. M. Bordeaux and P. H. Smith, Enhancement of anaerobic methanogenesis from napiergrass by addition of micronutrients. Biomass 11, 135-146 (1986).

11. G. M. Prine, L. S. Dunavin, B. J. Brecke, R. L. Stanley, P. Mislevy, R. S. Kalmbacher and D. R. Hensel. Model crop systems: sorghum, napiergrass. In Methane From Biomass: A Systems Approach (W. H. Smith and J. R. Frank, Eds), pp. 83-102. Elsevier Applied Science, New York (1987).

12. New York State College of Agriculture and Life Sciences. Cornell Field Crops and Soils Handbook, 2nd edition. 168 pp. Ithaca, New York (1987).

13. P. J. Van Soest and I. B. Robertson, Analysis of Forages and Fibrous Foods. Cornell University, Ithaca, New York (1986).

14. J. B. Robertson and P. J. Van Soest. In The Analysis of Dietary Fiber in Food (W. P. T. James and O. Theander, Eds), Marcel Dekker Inc., N.Y. (1981).

15. W. F. Owen, D. C. Stuckey, J. B. Healy, L. Y. Young and P. L. McCarty, Bioassay for monitoring biochemical methane potentials and anaerobic toxicity. Water Res. 13, 485-92 (1979).

16. B. K. Richards, R. J. Cummings, T. E. White and W. $J$. Jewell, Methods for kinetics analysis of methane fermentation in high solids biomass digesters. Biomass and Bioenergy 1, 65-73 (1991).

17. W. J. Jewell, R. J. Cummings, B. K. Richards, F. G Herndon and T. E. White, Engineering Design Considerations for Methane Fermentation of Energy Crops-Fundamental Investigations. Cornell University 1st Year (1988) Annual Report for the Gas Research Institute. GRI report No. GRI-91/0010. Chicago, Illinois, 60631 (1989).

18. G. F. Parkin and W. F. Owen, Fundamentals of anaerobic digestion of wastewater sludges. ASCE JEED 112(5): 867-920 (1986).

19. W. J. Jewell, R. J. Cummings, B. K. Richards, F. G. Herndon and T. E. White, Engineering Design Considerations for Methane Fermentation of Energy Crops--Fundamental Investigations. Cornell University 3rd Year (1990) Annual Report for the Gas Research Institute (GRI-91/0358). Chicago, Illinois, 60631. In preparation (1992). 